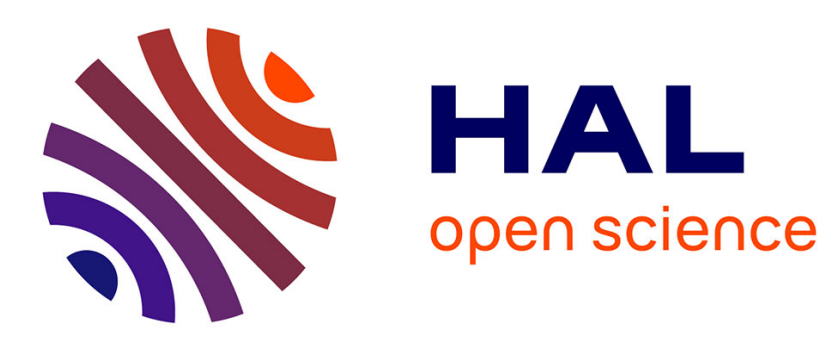

\title{
Temporal Variability of Atmospheric Lead Concentrations and Fluxes Over the Northwestern Mediterranean Sea
}

\author{
Emmanouela Remoudaki, G. Bergametti, P. Buat-Ménard
}

\section{To cite this version:}

Emmanouela Remoudaki, G. Bergametti, P. Buat-Ménard. Temporal Variability of Atmospheric Lead Concentrations and Fluxes Over the Northwestern Mediterranean Sea. Journal of Geophysical Research: Atmospheres, 1991, 96. hal-02326450

\section{HAL Id: hal-02326450 \\ https://hal.science/hal-02326450}

Submitted on 22 Oct 2019

HAL is a multi-disciplinary open access archive for the deposit and dissemination of scientific research documents, whether they are published or not. The documents may come from teaching and research institutions in France or abroad, or from public or private research centers.
L'archive ouverte pluridisciplinaire HAL, est destinée au dépôt et à la diffusion de documents scientifiques de niveau recherche, publiés ou non, émanant des établissements d'enseignement et de recherche français ou étrangers, des laboratoires publics ou privés. 


\title{
Temporal Variability of Atmospheric Lead Concentrations and Fluxes Over the Northwestern Mediterranean Sea
}

\author{
EMmanouel.a Remoudaki and Gil.I.ES BERgametTI \\ Laboratoire de Physico-Chimie de l'Aumosphdre, Université Paris 7, France \\ PATRICK BUAT-MÉNARD \\ Centre des Faibles Radioactivites, Gif-sur-Yvette, France
}

\begin{abstract}
Beginning in 1985, daily 24 -hour aerosol samples were collected on $0.4-\mu \mathrm{m}$ pore size filters at a coastal location in northwestern Corsica. Total atmospheric deposition (wet + dry) were sampled between February 1985 and October 1987 with a collection period of about 15 days. As indicated by three-dimentional air mass trajectories, lead aerosol particles collected at this site are primarily derived from European continental source regions. The variability of lead aerosol concentrations on both daily and seasonal time scales is primarily due to the scavenging of lead aerosol particles by rain rather than to changes in source regions. Our results suggest that the ratio between the total atmospheric deposition of $\mathrm{Pb}$ and the corresponding mean daily precipitation (mdp) rate is not constant. This ratio reaches a maximum during the Mediterranean summer. We attribute this difference to wet scavenging processes which wash a more loaded atmosphere during the dry season than during the wet season. The precipitation frequency $\left(F_{p}\right)$ is a major factor influencing seasonal variability of the total atmospheric deposition of lead over the westem Mediterranean. An intermediate value of $F_{p}$ allows sufficient reloading of the atmosphere with long-range transported $\mathrm{Pb}$ aerosol particles as well as efficient scavenging by precipitation events.
\end{abstract}

\section{INTRODUCTION}

During the last decade, it has become increasingly evident that the atmosphere is the major pathway for pollutant lead input to the world's ocean [Boyle et al., 1986]. This anthropogenic input outweighs natural inputs by orders of magnitude [Arimoto et al., 1985; Patterson and Settle, 1987]. Indeed, it has been shown that surface water maxima observed from measured concentration profiles of lead in North Pacific [Schaule and Patterson, ifo1, Flegal and Patterson, 1983] and North Atlantic [Schaule and Patterson, 1981, 1982] are the fingerprints of the atmospheric input of lead.

In a regional sea, such as the Mediterranean, the effects of the atmospheric input of lead aerosols are even more pronounced. Data obtained in western Mediterranean waters indicate an average $\mathrm{Pb}$ concentration of $60 \mathrm{ng} \mathrm{L}^{-1}$ in surface waters and an average concentration of $30 \mathrm{ng}$ $\mathrm{L}^{-1}$ in deep waters [Laumond et al., 1984]. These values are much higher than those observed in the Atlantic Ocean [Settle and Patterson, 1982] and in Pacific Ocean [Flegal and Patterson, 1983]. Observations of surface maxima confirm the atmospheric origin of $\mathrm{Pb}$. Previous works have suggested that this atmospheric lead is

\section{Copyright 1991 by the American Geophysical Union.}

Paper number 90JD00111.

0148-0227/91/90JD-00111\$05.00 primarily derived from European emissions [Arnold et al., 1982; Dulac et al., 1987; Maring et al., 1987]; 60\% of these emissions derive from vehicle exhaust due to gasoline alkyllead additives [Pacyna, 1984].

Data from various cruises in the Mediterranean Sea indicate an atmospheric $\mathrm{Pb}$ concentration range from 1.6 to $144 \mathrm{ng} \mathrm{m}^{-3}$ [Dulac et al., 1987]. Results from these cruises show also that the atmospheric $\mathrm{Pb}$ concentrations are highly variable on a daily time scale. This is due to changes in continental source strengths, airflow and precipitation patterns. Unfortunately, such data cannot provide a quantitative assessment of the atmospheric input to this basin, mainly because of the short duration of these campaigns.

In this paper, we have adressed this problem through a continuous sampling of total $\mathrm{Pb}$ atmospheric deposition at a coastal site of Corsica Island. From simultaneous measurements of lead contained in aerosol samples and data from air mass trajectory analyses and precipitation patterns, we have attempted to evaluate the major factors which control the deposition of lead to this marine area.

\section{SAMPLING AND ANAL YSIS}

\section{Aerosol Sampling}

Aerosol samples were collected at Capo Cavallo $\left(42^{\circ} 31\right.$ $\mathrm{N}, 8^{\circ} 40 \mathrm{E}$ ), on the northwestern coast of Corsica Island, between February 1985 and October 1987. We present here only results covering the period from February 1985 
to April 1986. The sampling site is located $300 \mathrm{~m}$ above sea level and is about $700 \mathrm{~m}$ distant from the shore line. It is exposed $80 \%$ of the time to marine air masses flowing southwest to northeast. Moreover, the closest local pollution sources, originating from the city of Calvi, are $20 \mathrm{~km}$ away from the site. The aerosol samples were collected at the top of a 10-m high meteorological tower. Bulk filtration samples were performed on $0.4-\mu \mathrm{m}$ porosity Nuclepore filters. Although the gaseous organic lead may represent up to $20 \%$ of the total atmospheric lead concentrations at maritime sites [Hewitt and Harrison, 1987], only particulate lead was sampled by bulk filtration. Sampling duration was 24 hours with a nominal airflow of $1 \mathrm{~m}^{3} \mathrm{~h}^{-1}$. The filtered air volume was measured by a volumetric Gallus counter with a precision better than $2 \%$. Blank filters were subjected to all the manipulations made on the filters, except air filtration.

\section{Total Deposition Sampling}

During the same period and at the same site, total (wet + dry) atmospheric deposition was sampled continuously with a collection period of about 15 days. We used a hemispherical polycarbonate collector having a collection surface area of $0.1 \mathrm{~m}^{2}$. The collector had been used to sample atmospheric deposition of radioactive aerosols [Lambert, 1963]. Results of this study have shown that this collector simulates satisfactorily the radioactive fallout onto the various surfaces [Lambert, 1963]. During our sampling, the collector was set up on a tripod so as to be $1 \mathrm{~m}$ above ground level. Its opening was covered by a nylon mesh (1 $\mathrm{mm} \times 1 \mathrm{~mm}$ mesh size) to avoid sampling perturbation from insects and leaves. A $5 \mathrm{~L}$ polyethylene bottle was connected to the collector. This bottle was kept in the dark inside a plastic enclosure to minimize bacterial development during sampling. The $5 \mathrm{~L}$ bottle was changed after each individual sampling period.

Numerous precautions were taken to minimize the contamination of the samples. The $5 \mathrm{~L}$ polyethylene bottles were precleaned in a clean room at the laboratory, according to the following procedure: rinsings with deionized water, soaking during 24 hours in a $2 \%$ detergent solution (Decon Prolabo), numerous rinsings with deionized water, rinsings with polished deionized water (Milli-Q), soaking during 3 weeks into a $0.1 \mathrm{~N}$ nitric acid solution (Normatom Prolabo), and numerous rinsings with polished deionized water (Milli-Q). After drying under ultraclean airflow, the bottles were closed into plastic bags and sent to the sampling site.

The $p \mathrm{H}$ conditioning is essential when analysis of trace metals is performed on the samples. At the beginning of each sampling period, the corresponding bottle contained $1 \mathrm{~L} \mathrm{HNO}_{3}$ (Normatom Prolabo) $0.1 \mathrm{~N}$ to prevent the sorption of metals onto its walls. At the end of the sampling, the hemispherical funnel of the collector was rinsed again with $1 \mathrm{~L} \mathrm{HNO}_{3} 0.1 \mathrm{~N}$ to recover the particles deposited on it. So each sample contains $2 \mathrm{~L}$ of nitric acid $0.1 \mathrm{~N}$ and the amount of all precipitation events occurring during the corresponding collection period. The above acidification served to keep the $p \mathrm{H}$ of the samples close to a value of 1 . The bottles containing the collected samples were wrapped in plastic bags and sent to the laboratory for treatment and analysis.

During the whole sampling period, the amount of precipitation (in $\mathrm{mm}$ ) corresponding to each event was measured using a standard rain gage operated by the French National Meteorological Station located at the sampling site. This allowed us to calculate the volume of precipitation (in liters) which should correspond to each sample (CPV in liters).

The volume of each sample represents the amount of collected precipitation to which $2 \mathrm{~L}$ of $\mathrm{HNO}_{3}$ Normatom Prolabo $0.1 \mathrm{~N}$ was added. The calculation of the regression line (total collected volume (TCV in liters) versus calculated precipitation volume (CPV in liters)) gave

$$
\mathrm{TCV}=0.76 \times \mathrm{CPV}+1.91
$$

with a correlation coefficient, $r=0.97$.

The intersect of this regression line represents the volume of the added acid and its slope the collection efficiency. The fact that the collection efficiency is lower than 1 is attributed to losses because of violent rains and/or evaporation.

During a short campaign at the sampling site in April 1986, we collected total deposition samples, using an ultraclean, one single-use collector at the top of the 10-m high meteorological tower $\left(\mathrm{TD}_{\mathrm{TL}}\right.$ :total deposition at the tower level) simultaneously, with our collector placed at the ground level (TD ${ }_{\mathrm{GL}}$ :total deposition at ground level). The results show a satisfactory reproducibility of the total deposition measurements for various elements between the two collection systems (Table 1). Such a comparison suggests the reliability of our collection system installed permanently at the sampling site, $1 \mathrm{~m}$ above ground level.

\section{Analysis}

All manipulations and analyses of samples were performed in the clean room of the laboratory. Laboratory material, brought into contact with samples, was precleaned according to the procedure described above for the sampling bottles.

For the aerosol samples, we present here only the concentrations of $\mathrm{Pb}$ determined by flameless atomic absorption spectrometry. Results concerning the concentrations of other elements have been presented in previous papers [Bergametti, 1987, Bergametti et al., 1989). For atomic absorption analysis, each sample is placed, for about 1 week, in a teflon bomb with $4 \mathrm{~mL}$ of $\mathrm{HNO}_{3}$ Normatom Prolabo and $1 \mathrm{~mL}$ of $\mathrm{HClO}_{4}$ Normatom 


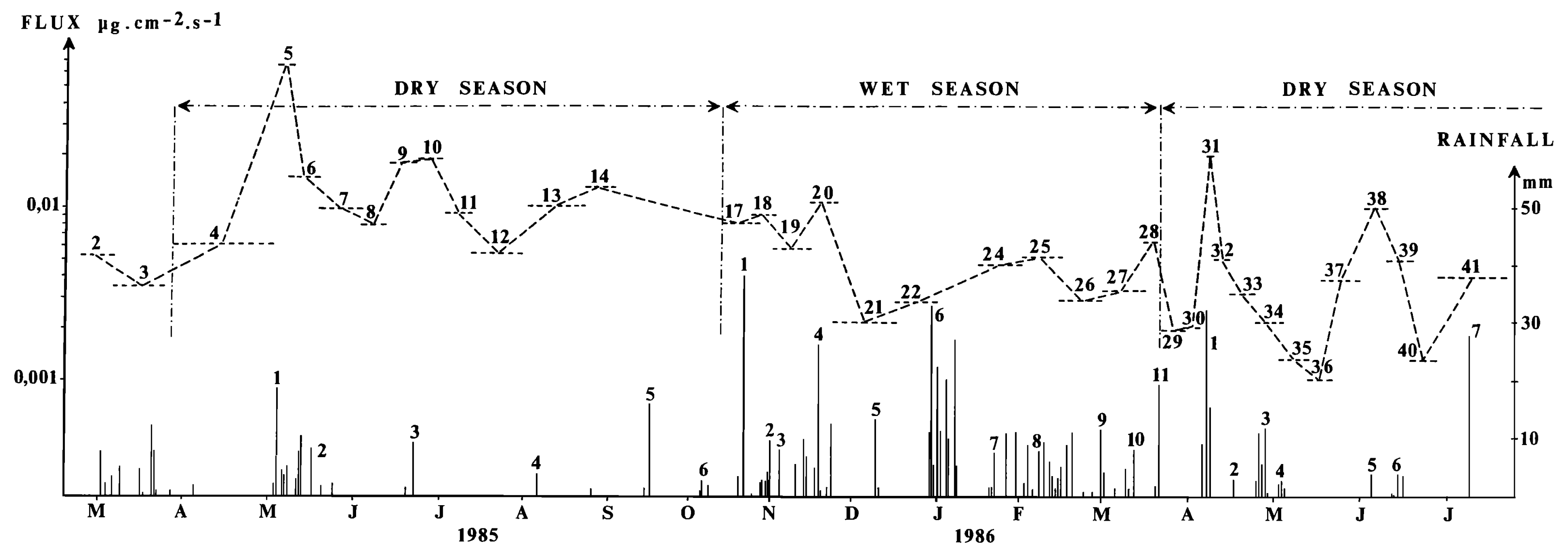

FLUX pg.cm-2.s-1

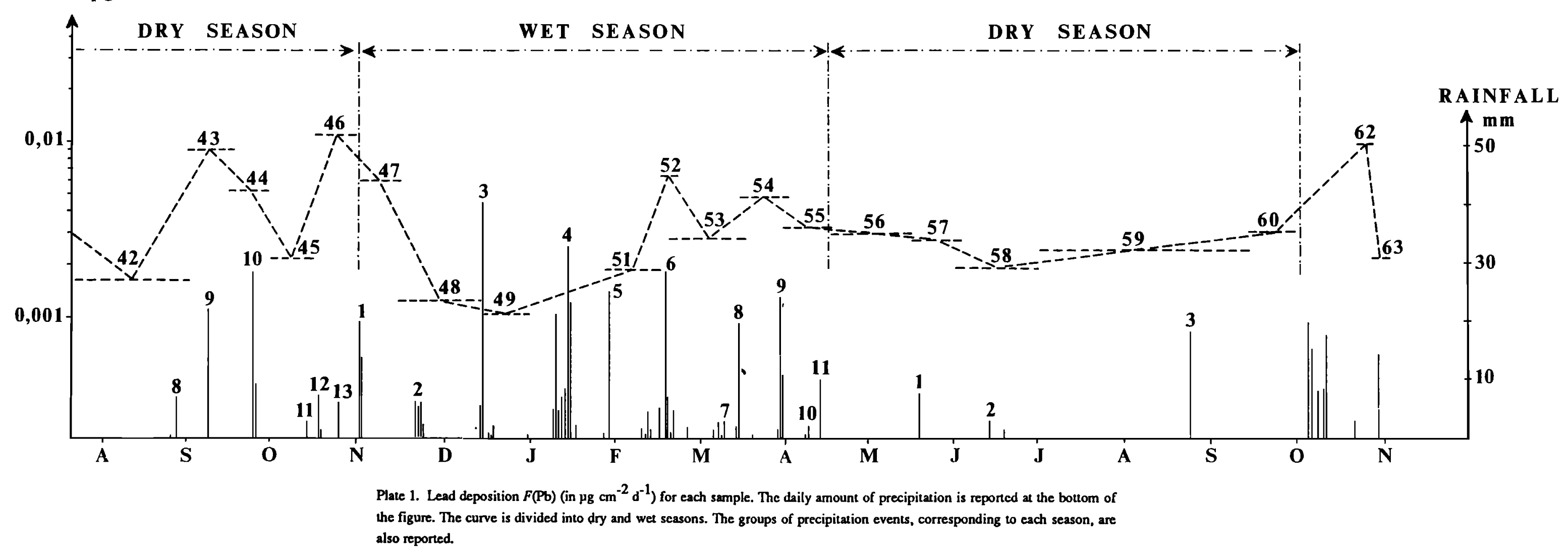



TABLE 1. Comparison Between Total Deposition Measurements at the Meteorological Tower Level $\left(\mathrm{TD}_{\mathrm{T}}\right)$ and Those at Ground Level $\left(\mathrm{TD}_{\mathrm{GL}}\right)$ for Various Elements in $\mu \mathrm{g} \mathrm{cm}^{-2} \mathrm{~d}^{-1}$.

\begin{tabular}{|c|c|c|c|c|c|c|}
\hline \multirow[t]{2}{*}{ Sample } & \multicolumn{2}{|c|}{$\mathbf{P b}$} & \multicolumn{2}{|c|}{$\mathbf{M n}$} & \multicolumn{2}{|c|}{ Al } \\
\hline & $\mathbf{T D}_{\mathrm{GL}}$ & $\mathrm{TD}_{\mathbf{T}}$ & $\mathbf{T D}_{\mathrm{GL}}$ & $\mathbf{T D}_{\mathbf{n}}$ & $\mathrm{TD}_{\mathrm{GL}}$ & $\mathbf{T D}_{\mathbf{T}}$ \\
\hline 31 & 0.019 & 0.020 & 0.024 & 0.035 & 1.6 & 2.1 \\
\hline 32 & 0.0049 & 0.0028 & 0.0011 & 0.0012 & 0.077 & 0.070 \\
\hline 33 & 0.0031 & 0.0026 & 0.0021 & 0.0029 & 0.106 & 0.102 \\
\hline
\end{tabular}

Prolabo at a temperature of $60^{\circ} \mathrm{C}$. The liquid residue (about $1 \mathrm{~mL}$ ) is then ajusted to $5 \mathrm{~mL}$ with Milli-Q water. Working standards were prepared in a similar solution to allow matrix matching with samples. The analysis was performed by using a Perkin Elmer model 400 unit with HGA 500 graphite furnace. Mean relative errors have been estimated to be $10 \%$.

Total atmospheric deposition samples were filtered on Nuclepore filters $(0.4 \mu \mathrm{m}$ pore size) to separate the particulate from the dissolved fraction. The analysis of the dissolved fraction has been performed directly without any preconcentration, by flame atomic absorption spectrometry (Perkin Elmer 300) for $\mathrm{Na}$ and flameless atomic absorption spectroscopy for $\mathrm{Pb}$ (using the above unit). Experimental evidence showed that $\mathrm{Pb}$ is $100 \%$ soluble in our acidified samples ( $p \mathrm{H}$ about 1). iAnalytical errors have been calculated to be $10 \%$ for $\mathrm{Pb}$ and $\mathrm{Na}$ for a probability of $90 \%$ and according to the calibration curve method described by Feinberg [1984]. Blank samples, subjected to all manipulations made on the real samples, gave lower signals than the signal corresponding to the detection limit of lead. This limit was determined to be 2 $\mu \mathrm{L} \mathrm{L}^{-1}$ using the above calibration curve method. An intercalibration test was performed with anodic stripping voltametry for 11 samples. The calculation of the regression lines gave

$$
\begin{aligned}
& \mathrm{Pb}_{A S V} \text { versus } \mathrm{Pb}_{\text {GFAAS }} \mathrm{Pb}_{\text {ASV }}=0.80 \times \mathrm{Pb}_{\text {GPAAS }}+9.3 \\
& \mathrm{~Pb}_{\text {GPAAS }} \text { versus } \mathrm{Pb}_{\text {ASV }} \mathrm{Pb}_{\text {GPAAS }}=1.06 \times \mathrm{Pb}_{\text {ASV }}-1.8
\end{aligned}
$$

with a correlation coefficient, $r=0.92$.

\section{RESULTS AND DISCUSSION}

\section{Temporal Variability of Lead \\ Aerosol Concentrations}

The yearly geometric mean aerosol concentration of lead at Capo Cavallo for the study period is $15.9 \mathrm{ng} \mathrm{m}^{-3}$. Lead aerosol concentrations are highly variable on a time scale of 1 day (Figure 1). Such a high variability confirms the observations of Dulac et al.. [1987].
Our data also indicate a seasonal pattern for particulate lead concentrations in the western Mediterranean atmosphere: during the dry period (May-October) the geometric mean concentration is about $24 \mathrm{ng} \mathrm{m}^{-3}$ while during the wet period (October-May) the geometric mean concentration is only $11.8 \mathrm{ng} \mathrm{m}^{-3}$. This seasonal pattem is also observed for other elements of continental origin (natural and man made) [Bergametti et al., 1989] and is inversely related to that of precipitation. At first glance, our data suggest that precipitation is a major factor influencing the variability of the measured aerosol lead concentrations. Indeed, it appears from Figure 1 that precipitation events are systematically followed by abrupt decreases of the aerosol lead concentration. To properly assess this influence, however, we have to consider simultaneously the variability induced by changes in source regions and air flow patterns.

Influence of the source regions. For each sample, we have computed three-dimensional 4-day backward air mass trajectories [Imbard, 1983; Bergametti et al., 1989]. Briefly, the calculation assumes that the instantaneous movement of the air mass is equal to the wind vector at the center of the air mass. This wind vector is computed, every $5 \mathrm{~min}$, by linear, spatial, and temporal interpolation [Imbard, 1983] from the three-dimensional wind field analyzed at the European Center for Medium Term Meteorological Forecasts, in Reading, England. Moreover, along these trajectories, the model reports the forecasted precipitations greater than $0.1 \mathrm{~mm} \mathrm{~h}^{-1}$. Our trajectories were calculated for the midpoint of each sampling period and finished at the $925 \mathrm{hPa}$ barometric level.

To classify the samples with respect to the origin of the air masses, we made no "a priori" hypotheses concerning the various source regions of lead for the western Mediterranean atmosphere. We divided a wind rose into 16 sectors of $22^{\circ} 5$, and each sample was classified in the $22^{\circ} 5$ sector corresponding to the position of the air masses 2 days before their arrival over the sampling site. However, some trajectories were too short and consequently, it was difficult to assign a precise source region. Thus we defined a seventeenth sector for these particular trajectories.

As previously mentioned, local precipitation may strongly change atmospheric lead concentrations on a short time scale and thus affect the "fingerprints" of the source regions. Thus we have not considered the samples collected when local precipitation occurred. Further, because the mean reloading time of the local atmosphere with continental aerosols following a local rain has been estimated to be about 2 days [Bergametti et al., 1989], the samples for which a local precipitation occurred 2 days or less before sampling were also excluded.

For each sector, we calculated the geometric mean aerosol concentration and we grouped together adjacent sectors when the mean concentrations were found to be similar. The results of these calculations are illustrated in 


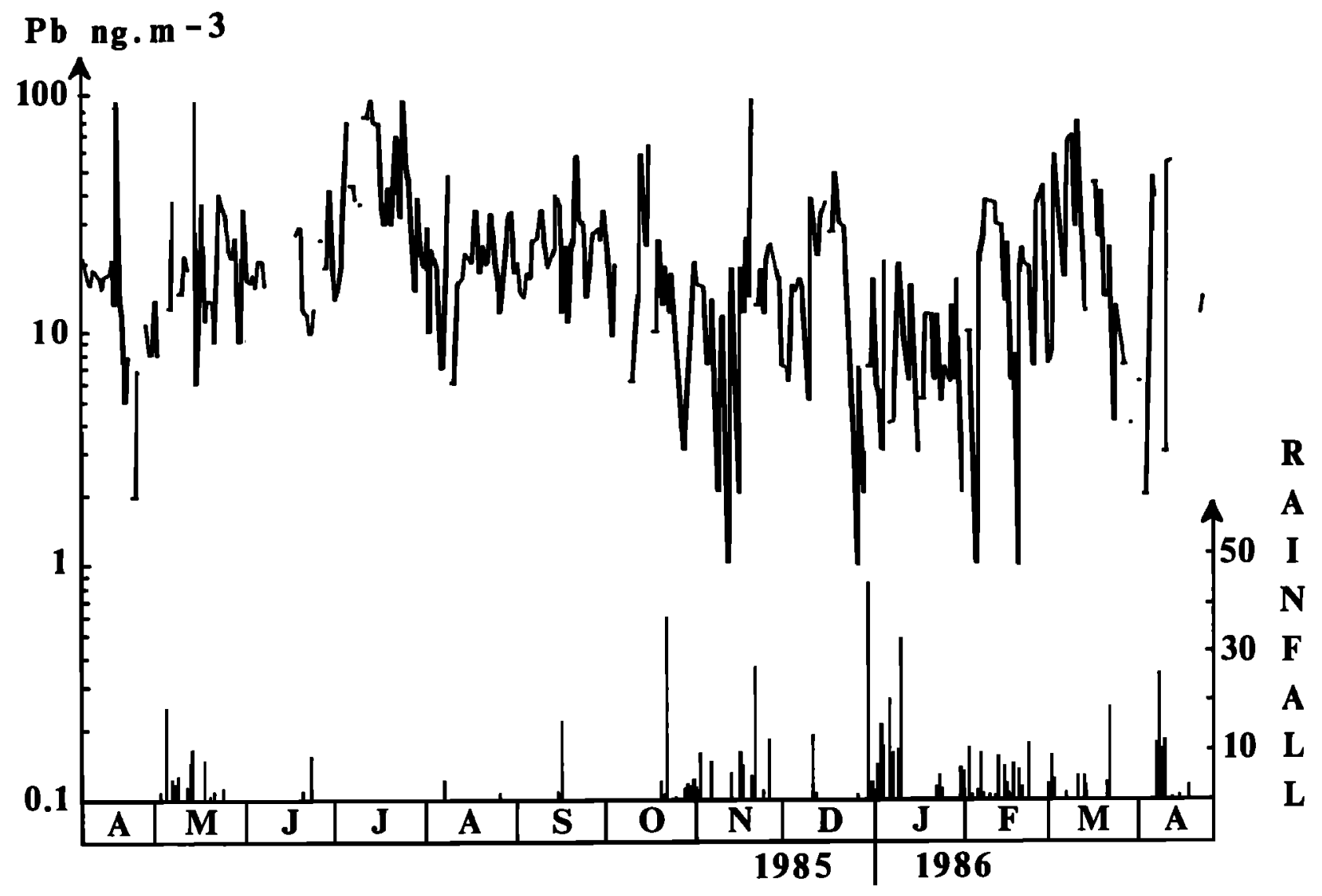

Fig. 1. Daily atmospheric concentrations (in $\mathrm{ng} \mathrm{m}^{-3}$ ) of $\mathrm{Pb}$ a Capo Cavallo for the period February 1985 to April 1986. The daily amount of local precipitation is reported at the bottom of the figure.

Figure 2 . The highest concentrations are associated with transport cases from north-northeast $\left(27 \mathrm{ng} \mathrm{m}^{-3}\right)$ and west (21.9 $\mathrm{ng} \mathrm{m}^{-3}$ ). In contrast, the south sector, corresponding to air masses coming from North African countries, exhibits the lowest concentrations of lead $\left(7.4 \mathrm{ng} \mathrm{m}^{-3}\right)$. This may be due to the low industrial activity and vehicular traffic in these countries.

Northwest and southeast sectors and the sector corresponding to the shortest trajectories are associated with intermediate concentrations of lead $(16.1,16.8$, and $18 \mathrm{ng} \mathrm{m}^{-3}$ respectively).

Such a classification does not, however, provide any direct quantitative information on the emission rates of lead in the various source regions. Indeed, it will be shown that such an assessment requires the separation of air masses washed during their transport from those transported during "dry" conditions.

Influence of rain occuring during transport. To estimate the influence of rains, we have used the precipitation events forecast by the trajectory model. Only two sectors (for which the number of samples was sufficient, i.e., the northwest and the northeast) have been selected. The samples were separated to three groups: (1) samples for which a precipitation event occurred during the last day of transport, (2) samples for which a precipitation event occurred 2 days before the arrival of the air mass over the sampling site, and (3) samples with no precipitation event during the last 2 days of transport.

The results presented in Figure 3 show a strong influence of the occurrence of precipitation during air mass transport on the aerosol concentrations of lead. For the northwest sector, mean $\mathrm{Pb}$ concentrations in air masses washed during the last 24 hours before their arrival at Corsica (7.2 $\mathrm{ng} \mathrm{m}^{-3}$, group 1) are 4 times lower than those corresponding to dry transport cases $(28.5 \mathrm{ng}$ $\mathrm{m}^{-3}$, group 3). The second group (rain in the 1-2 days interval) exhibits intermediate $\mathrm{Pb}$ concentrations.

Similar results are obtained for the northeast sector with only a factor of 2 between the two extreme cases (17.7 $\mathrm{ng} \mathrm{m}^{-3}$, group 1 , and $31.9 \mathrm{ng} \mathrm{m}^{-3}$, group 3 ). There is only a small difference between samples corresponding to groups (2) and (3).

The different pictures obtained for northwest and northeast sectors can be explained when considering the distances separating Corsica from the Mediterranean coast lines. For the Northeast sector the distance between Corsica and the Mediterranean coast corresponds generally to 1 day of transport. In this case, air masses, washed 2 days before arriving in Corsica, can be reloaded by the emissions of industrial and urban areas located on 


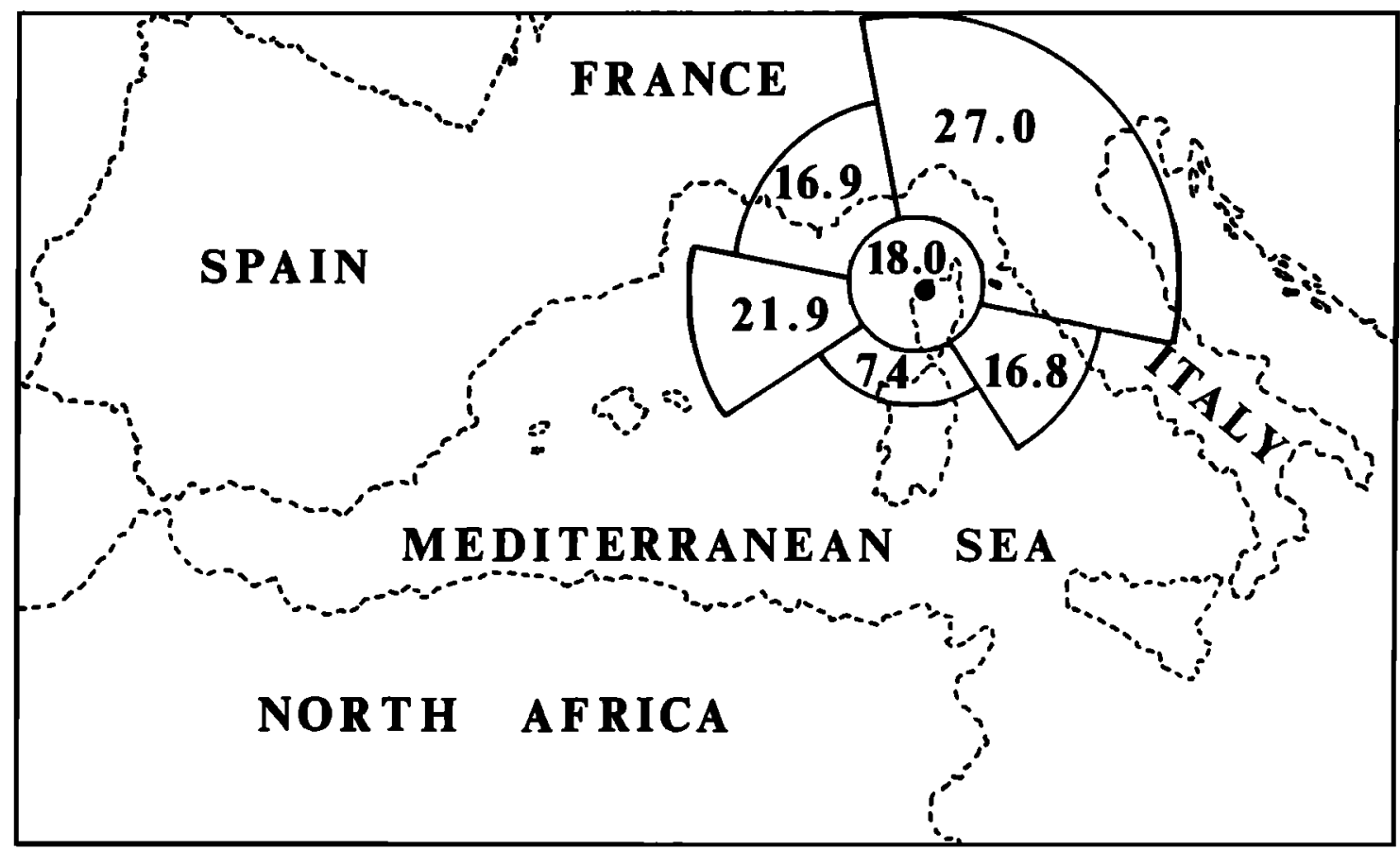

Fig. 2. Classification of $\mathrm{Pb}$ concentrations (in $\mathrm{ng} \mathrm{m}^{-3}$ ) according to the origin of the air masses arriving at the sampling site (the small circle corresponds to short trajectories).

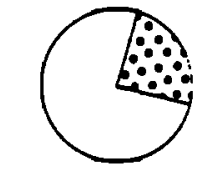

\section{East sector}

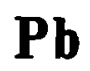

$\mathbf{P b}$

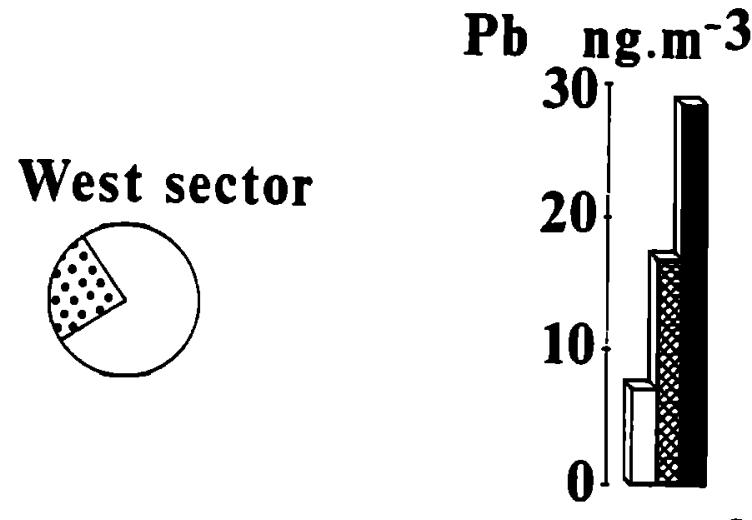

$\mathbf{P b}$

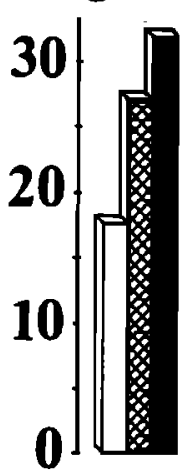

Fig. 3. Influence of precipitations occurring during the transport of the aerosol particles on the concentrations of lead (in $\mathrm{ng} \mathrm{m}^{-3}$ ) at Capo Cavallo; samples affected by : a rain event during the last 24 hours (white bar); a rain event two days before the arrival of the air mass on the sampling site (cross-ruled bar); no rain event during the last $\mathbf{4 8}$ hours (black bar). the Italian and French Rivieras. For air masses originating from the northwest, 2 days of transport are generally necessary for travel from the French or Spanish coasts to Corsica. In this case, the air masses cannot be reloaded during their travel over the sea.

For the northwest sector, the mean $\mathrm{Pb}$ concentrations range between $7.2 \mathrm{ng} \mathrm{m}^{-3}$ (group 1) and $28.5 \mathrm{ng} \mathrm{m}^{-3}$ (group 3). This range is similar to that observed from the classification in the various sectors (Figure 2). Moreover, if we consider now the non washed air masses (group 3, Figure 3), the difference in lead concentrations is not significant between the northwest and the northeast sector.

It can therefore be concluded that precipitation occurring during transport is the major factor controlling the variability of lead concentrations in the Western Mediterranean atmosphere.

\section{Atmospheric Lead Deposition into the Western Mediterranean}

Temporal variability of atmospheric lead deposition. Fifty-seven total deposition samples (wet + dry) have been collected between February 1985 and October 1987. The measured deposition of lead for each sample and the corresponding mean daily precipitation rate (mdp) are reported in Figure 4. The temporal variability of these two parameters is quite similar. The highest $\mathrm{Pb}$ fluxes appear almost systematically when the mdp exhibits a high value. In contrast, the lowest $\mathrm{Pb}$ fluxes correspond to periods with no or little precipitation. This suggests that the high $\mathrm{Pb}$ fluxes result primarily from wet deposition. This is in 


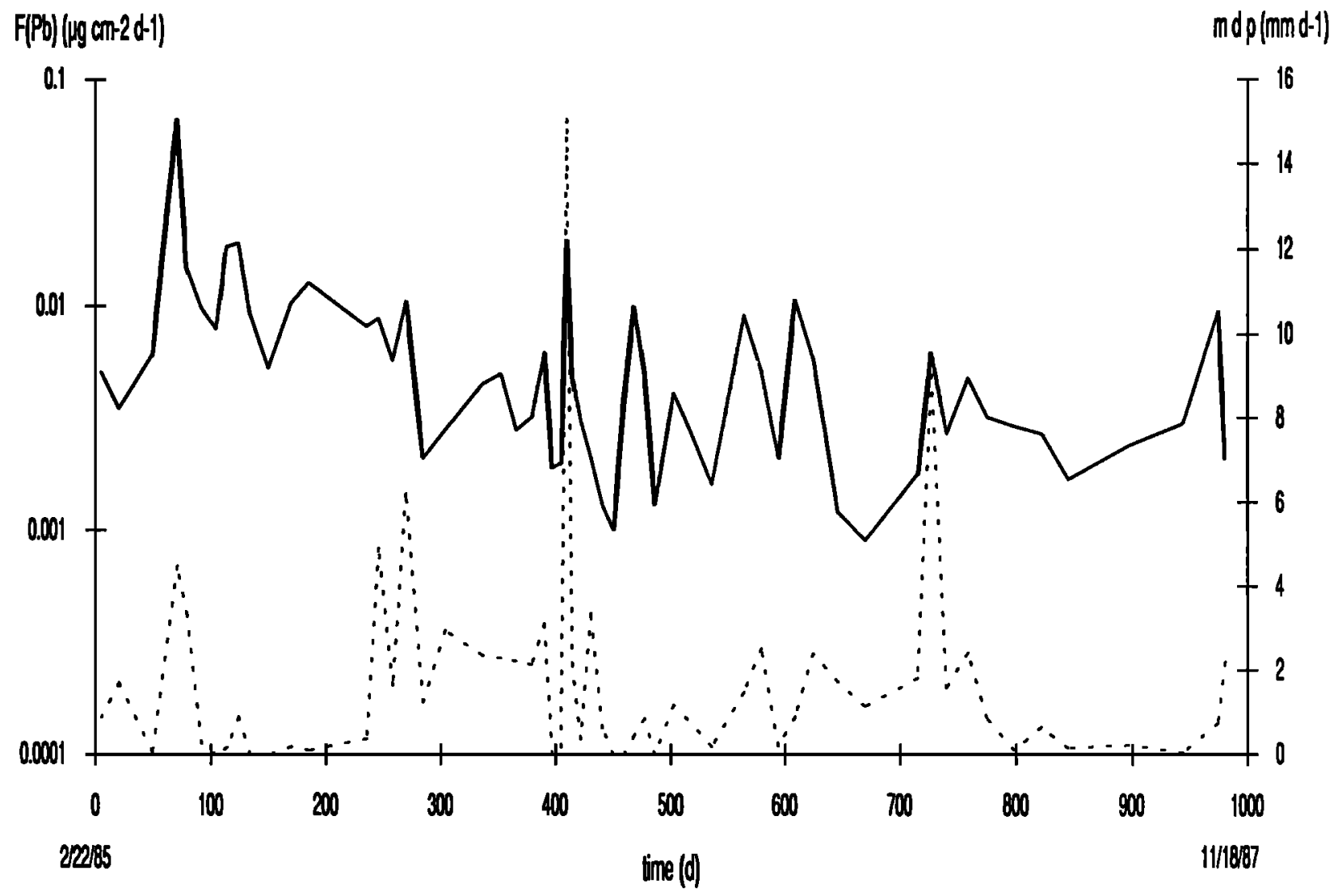

Fig. 4. Solid line: temporal variability of lead deposition $F(\mathrm{~Pb})$ (in $\mu \mathrm{g} \mathrm{cm} \mathrm{m}^{-2}$ for each sample). Dotted line: mean daily precipitation mdp (in $\mathrm{mm} \mathrm{d}^{-1}$ ) corresponding to each sample.

agreement with what is generally observed in the marine atmosphere [Galloway et al., 1982].

Relationship between atmospheric lead deposition and local precipitation. As indicated in Figure 5 , it is apparent that the ratio between the lead flux and the corresponding mdp is not constant. This ratio is higher during spring and summer. This clearly suggests that atmospheric lead fluxes to marine areas cannot be estimated by algorithms linearly relating the $\mathrm{Pb}$ flux to the mdp. This can be explained by the combined influence of two factors: the scavenging of the aerosol particles by wet and/or dry deposition, and the concentration of the element in the air column over the sampling site.

Influence of dry deposition. The low values of mdp, during the dry season, could mean that dry deposition contributes significantly to the total deposition of $\mathrm{Pb}$. To test this assumption, we calculated apparent dry deposition velocities using measured dry flux data and arithmetic mean aerosol concentrations corresponding to the duration of each sample.

The mean value of the dry deposition velocity of $\mathrm{Pb}$ is $1.8 \mathrm{~cm} \mathrm{~s}^{-1}$. This value is in good agreement with those measured using surrogate surfaces at other coastal or island sites ( 0.6 to $0.8 \mathrm{~cm} \mathrm{~s}^{-1}$ ) [Cambray et al., 1975]. However, the measured value of $\mathrm{Pb}$ dry deposition velocity in this work is surprisingly high compared to values found using a modeling approach. Dulac et al. [1989] calculated a value of $0.05 \mathrm{~cm} \mathrm{~s}^{-1}$ based on observed mass-size distribution of lead and, the dry deposition model of Slinn and Slinn [1980]. The use of a surrogate surface to measure dry deposition rates introduces a significant uncertainty coming from the properties of such a surface. However, it is difficult to quantify this uncertainty by comparing our measured dry deposition velocity with those calculated by a modeling approach. This difficulty is mainly due to the uncertainties existing in dry deposition modeling. Sievering [1984] has suggested that the uncertainty in modeling dry deposition of small particles (D close to 1 $\mu \mathrm{m})$ to natural water surfaces is about an order of magnitude.

A possible explanation is that factors such as the occurrence of fog may be responsible for the high value of the observed mean dry deposition velocity. Indeed, fog episodes have been reported at our sampling site during periods with no precipitation. Hence the "dry" scavenging of aerosol particles during such periods likely includes the effect of $\mathrm{Pb}$ scavenging by fog droplets.

Using our data, total (wet + dry) deposition velocities have been calculated for the samples presenting a mean daily precipitation rate lower than $1 \mathrm{~mm} \mathrm{~d}^{-1}$. The total deposition velocities ranged from 4 to $16 \mathrm{~cm} \mathrm{~s}^{-1}$. This 


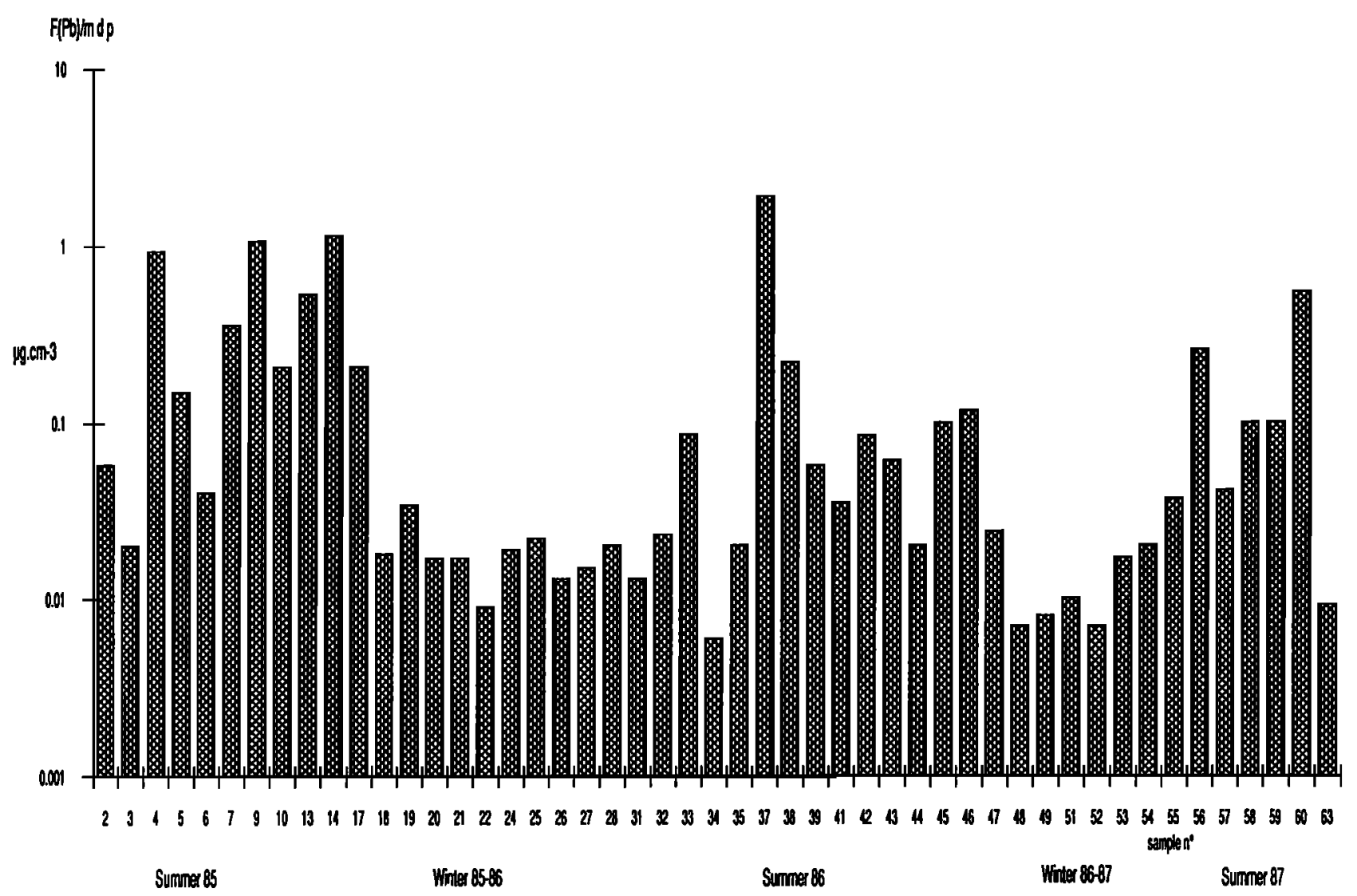

Fig. 5. Ratios between the aumospheric lead deposition $F(\mathrm{~Pb})\left(\right.$ in $\mu \mathrm{g} \mathrm{cm}^{-2} \mathrm{~d}^{-1}$ ) and the corresponding mean daily precipitation rate (in $\mathrm{cm} \mathrm{d}^{-1}$ ) for each sample.

clearly suggests that dry deposition accounts for a minor fraction of the total $\mathrm{Pb}$ deposition flux even when precipitation events are scarce. Consequently, the relative fraction of dry deposition in our samples does not explain the large variation of the ratio $\mathrm{F}_{\mathrm{Pb}} /$ mdp.

Relationship between atmospheric deposition of lead and the occurrence of rainy days. In Figure $6 a$ we have reported the $\mathrm{Pb}$ fluxes after application of a moving mean method to our data, with a time span of about 60 days. In the same figure, we have reported the occurrence of the rainy days using the same method. These results suggest that the major factor which controls the temporal variability of lead deposition is related to the ability of $\mathrm{Pb}$ to be transported from the source regions to the sampling area. This hypothesis is strongly supported by the comparison between the $\mathrm{Pb}$ and $\mathrm{Na}$ fluxes (Figure $6 b$ ). Indeed, $\mathrm{Na}$ is primarily present as locally produced seasalt aerosol. Na deposition is therefore independent of transport processes. We observe that sodium deposition becomes important during the "rainy" season and is at a minimum during the "dry" season. Such behavior can be attributed to a very fast reloading of the local atmosphere, following a rain event, with locally produced sea-salt aerosol. The deposition of $\mathrm{Na}$ is enhanced during the rainy season because of the more frequent scavenging of the atmosphere by precipitation. In contrast, sea salt aerosol particles are less frequently scavenged by precipitation events during the dry season (Figure $6 b$ ).

On the other hand, total $\mathbf{P b}$ deposition is highest during the dry season and lowest during the rainy season (Figure 6a). In addition, the variations of lead deposition are anticorrelated with those of the occurrence of the rainy days. The low $\mathrm{Pb}$ deposition values during the Mediterranean "winter" can be ascribed to the fact that the atmosphere being scavenged by rain is characterized by a relatively low $\mathrm{Pb}$ aerosol content.

Influence of local precipitation frequency on the seasonal variability of $P b$ deposition. As discussed previously, the existence of low atmospheric $\mathrm{Pb}$ concentrations during the rainy season can be explained by two closely connected arguments. First, since lead concentrations result from transport from continental sources, the aerosol particles containing lead are frequently washed out by precipitation events before their arrival over the sampling site. Second, during the rainy season, there is not sufficient time between two rain events to reload the atmosphere of the receptor site with $\mathrm{Pb}$ aerosol particles.

Thus it is expected that the time needed for a sufficient reloading of the receptor atmosphere is longer than the time interval between two rain events during the Mediterranean winter. To test this assumption, we have 


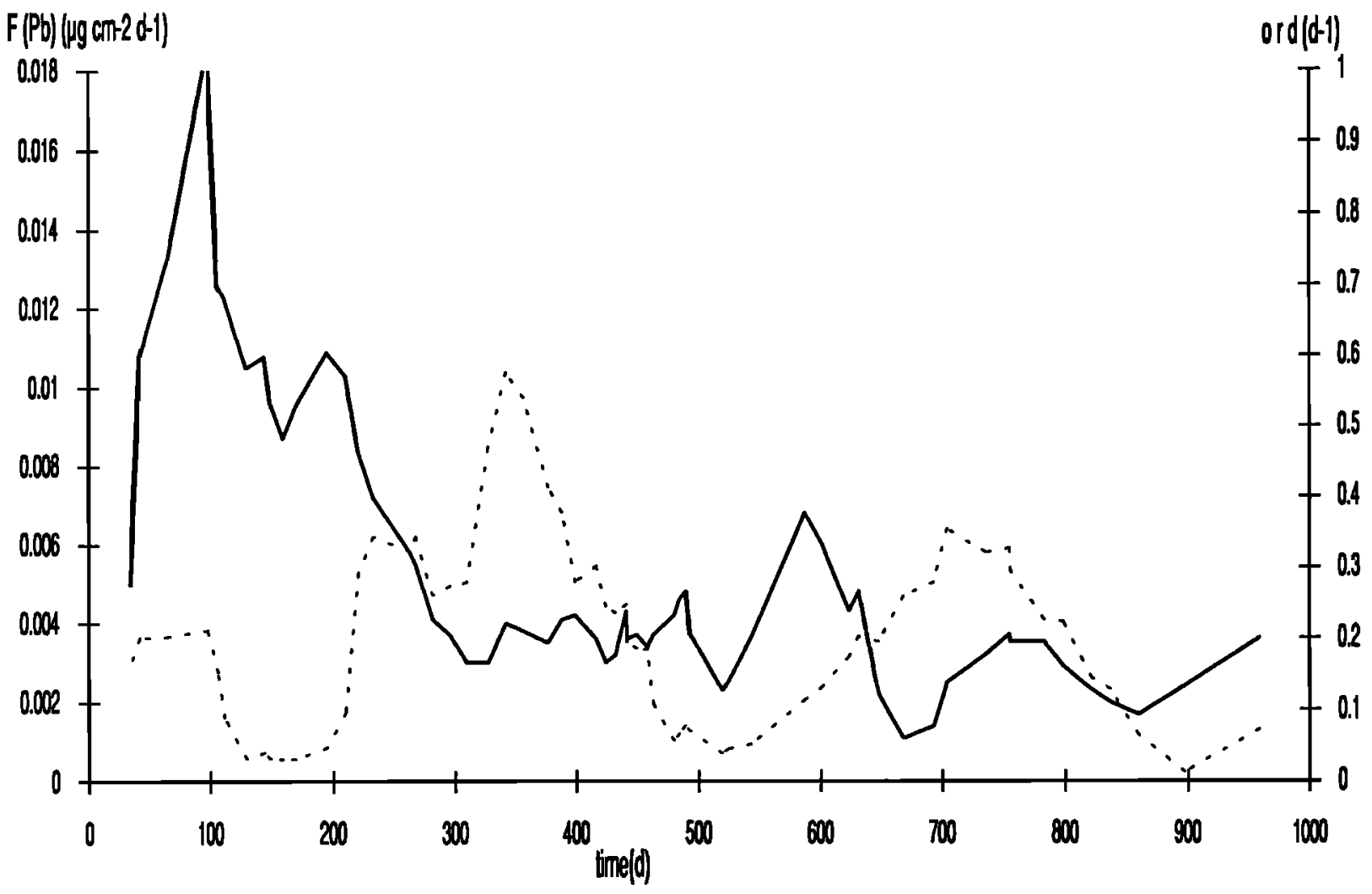

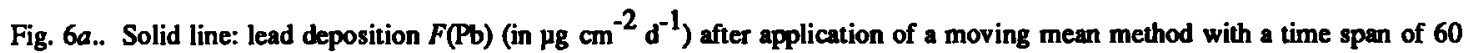
days. Dotted line: occurrence of the rainy days (ord. in $\mathrm{d}^{-1}$ ) from local precipitation data, after application of the moving mean method with the above time span. The occurrence of the rainy days (in $\mathrm{d}^{-1}$ ) is defined as the number of the rainy days during a sample divided by the duration of the sample in days.

$F(N a)$ (Ig.crm-2d-1)

o.r.d. (d. $(0-1)$

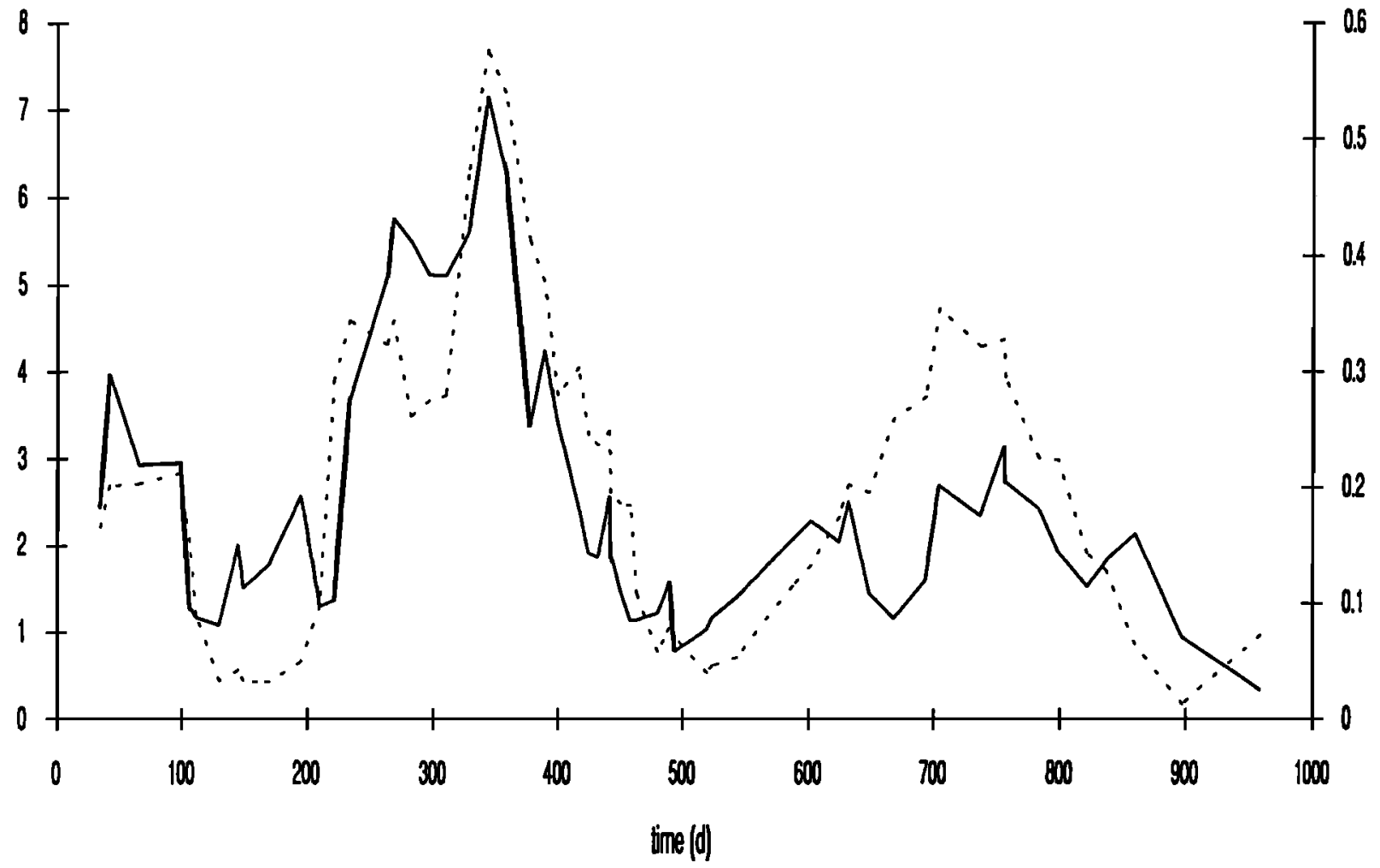

Fig. $6 b$. Solid line: sodium deposition $F(\mathrm{Na})$ (in $\mu \mathrm{g} \mathrm{cm}^{-2} \mathrm{~d}^{-1}$ ) after application of a moving mean method with the above time span. Dotted line: the same as in Figure 6a.. 
used data on precipitation forecast by the air mass trajectory model used in this work. The occurrence of precipitation events, during the transport of the air masses, was found relatively well correlated with the occurrence of local precipitation at Capo Cavallo. Local precipitation data for the whole sampling period were therefore used to estimate the effect of the local removal of lead aerosol particles by wet deposition and the scavenging of atmospheric lead during transport from the source regions to the sampling site.

If we now consider the temporal variation of total $\mathrm{Pb}$ deposition (Plate1), we observe that the highest $\mathrm{Pb}$ fluxes correspond systematically to sampling periods characterized by the absence of rain during at least the first 4 days of sampling and the occurrence of precipitation events in the end of the sampling (i.e., samples 9, 10, 13, 28, 43, 54). High $\mathrm{Pb}$ fluxes are also observed if rain occurred during a sampling period preceded by a "dry" period of 4 days at least (i.e., samples $5,31,41,46,52)$. The lowest $\mathrm{Pb}$ deposition values correspond to sampling periods with no precipitation (8, $11,12,29,30,36,40$ ) and/or to sampling periods preceded by precipitation events (i.e., samples $3,6,19$, $21,26,42,45$ ).

These observations suggest that the high values of $\mathrm{Pb}$ fluxes result from wet deposition, primarily when precipitation events occur after a long dry period.

As shown in Figure 1, we divided the sampling period into dry and wet seasons. For both seasons, we defined the frequency of the precipitation periods $F_{p}$ as the number of groups of precipitation events divided by the duration of the corresponding period in days. The groups of precipitation events are separated from each other by a period of 4 "dry" days at least.

$\mathrm{Pb}$ and $\mathrm{Na}$ deposition fluxes as well as the frequency of the precipitation periods $F_{p}$ corresponding to each season are reported in Table 2. These results allow us to conclude that the frequency of the precipitation periods influences the following factors.

The degree of loading of the receptor atmosphere with $\mathrm{Pb}$ aerosol_particles: High values of $F_{p}$ imply that the atmosphere does not have the time to be sufficiently reloaded with aerosol particles of continental origin. Thus the $\mathrm{Pb}$ deposition presents low values during both rainy seasons (1985-1986, 1986-1987). On the other hand, during summer 1986, the atmosphere was frequently scavenged by rains. This period therefore cannot be classified as a "normal" dry season. The value of the total $\mathrm{Pb}$ deposition during summer 1986 is lower than that observed during summer 1985, but higher than that observed during both rainy seasons (Table 2).

The relative importance of wet and dry deposition of lead: A low value of $F_{p}$ implies that dry deposition may become significant. For example, the value of the $\mathrm{Pb}$ flux during summer 1987 can be ascribed to the lack of precipitation. Indeed, as previously discussed, dry deposition processes are less efficient in removing $\mathrm{Pb}$ aerosol particles than precipitation scavenging. Consequently, in such a case, even if the local atmosphere has a high lead content, the corresponding $\mathrm{Pb}$ deposition flux is low.

These two influences of $F_{p}$ on the seasonal variability of $\mathrm{Pb}$ fluxes seem to be operating simultaneously during summer 1985. An intermediate value of $F_{p}$ allows sufficient reloading of the local atmosphere with $\mathrm{Pb}$ aerosol particles as well as efficient scavenging by precipitation events. In this case, the $\mathrm{Pb}$ deposition flux is the highest observed.

\section{CONCLUDING REMARKS}

We have shown that the variability of aerosol lead concentrations on both daily and seasonal time scales is primarily due to the scavenging of lead aerosol particles by rain rather than to changes in source regions.

On a daily time scale, local precipitation events are responsible for the sharpest decreases of atmospheric lead concentrations.

On a seasonal time scale, rains occurring during transport, as well as locally, generate a seasonal cycle for lead concentrations in the western Mediterranean atmosphere with high atmospheric concentrations during the dry season and low concentrations during the wet season.

Our results suggest that the ratio between the $\mathrm{Pb}$ flux and the corresponding mdp is not constant. This ratio reaches a maximum during the Mediterranean summer. We attribute this difference to the fact that the local

TAELE 2. Seasonal $\mathrm{Pb}$ and $\mathrm{Na}$ Deposition and the Corresponding Frequency of Precipitation

\begin{tabular}{|c|c|c|c|c|c|c|}
\hline Date Begin & Date End & Season & Sample & $\begin{array}{l}F_{p} \\
d^{-1}\end{array}$ & $\begin{array}{c}F \mathrm{~Pb} \\
\mu \mathrm{cm}^{-2} \mathrm{~d}^{-1}\end{array}$ & $\begin{array}{c}F \mathrm{Na} \\
\mu \mathrm{cm}^{-2} \mathrm{~d}^{-1}\end{array}$ \\
\hline Mar. 25, 1985 & Oct. 11, 1986 & dry & $4-14$ & 0.030 & 0.0118 & 2.3 \\
\hline Oct. 11, 1985 & Mar. 22, 1986 & wet & $17-28$ & 0.074 & 0.0025 & 5.2 \\
\hline Mar. 22, 1986 & Nov. 01, 1986 & dry & $29-46$ & 0.058 & 0.0042 & 1.7 \\
\hline Nov. 01, 1986 & Apr. 16,1987 & wet & $47-55$ & 0.079 & 0.0028 & 2.2 \\
\hline Apr. 16, 1987 & Oct. 02, 1987 & dry & $56-60$ & 0.018 & 0.0024 & 1.1 \\
\hline
\end{tabular}


atmosphere is more heavily loaded with lead during the "dry" season.

As a consequence, the seasonal variability of $\mathrm{Pb}$ deposition is more pronounced when the frequency of precipitation events occurring during the dry season, exhibits an intermediate value. There is probably a lower and ân üppér limit fơr this iniermediaie vaiue of $F_{p}$. Above this upper limit, the seasonal variability of $\mathrm{Pb}$ fluxes becomes less pronounced, as was the case during summer 1986. In contrast, below the lower limit (i.e., summer 1987), the $\mathrm{Pb}$ fluxes may become less important than those corresponding to the rainy season.

Our measurements also show that, during rainy periods, $\mathrm{Pb}$ is not transported efficiently to the open sea. This implies that during the rainy period, $\mathrm{Pb}$ atmospheric deposition measured at Capo Cavallo is probably much lower than that occurring at the same time on the continental shore line, where the $\mathrm{Pb}$ deposition flux is probably better correlated with the occurrence of the rainy days. Hence the open sea is probably more affected by atmospheric $\mathrm{Pb}$ input during the dry season, while the continental coastal regions are probably more affected during the wet season. We can therefore expect both a spatial and a temporal pattern of $\mathrm{Pb}$ deposition to the western Mediterranean. This raises some doubts about the validity of extrapolating lead deposition fluxes from a single sampling site to the entire basin.

The annual flux of lead for the first year of measurements (from March 25, 1985 to March 22, 1986), was $3.1 \mu \mathrm{g} \mathrm{cm}^{-2} \mathrm{yr}^{-1}$, while for the second year (from March 22, 1986 to April 16, 1987) this flux was only 1.5 $\mu \mathrm{g} \mathrm{cm}^{-2} \mathrm{y}^{-1}$. So a significant interannual variability is also observed at our sampling site. This primarily results from the different $\mathrm{Pb}$ deposition fluxes recordered during the two dry seasons.

Finally, we stress that the impact of the atmospheric input on $\mathrm{Pb}$ concentrations in the surface waters of this area is to be more pronounced during summer and fall. This is because of the high $\mathrm{Pb}$ deposition flux during this period of the year and the existence of a well-developed surface mixed layer in the Mediterranean waters (of about $50 \mathrm{~m}$ depth) which favors the buildup of atmospherically derived lead inputs.

Acknowledgments. We wish to thank the staff of the signal station of Capo Cavallo for logistical support during the field experiments in Corsica. We also thank the French Marine Nationale for free access to the signal station and the French Direction de la Météorologie Nationale for use of the meteorological tower at Capo Cavallo. We are grateful to $\mathbf{R}$. Losno, B. Chatenet, L. Gomes, A. Dutot and F. Dulac for assistance in sampling and analysis and for helpful discussion and to E. Bon Nguyen for illustration. We are particularly grateful to D. Martin, B. Strauss, and J. M. Gros, who computed the air mass trajectories. This work was supported in part by the Ministère de l'Environnement, the Programme Flux Océanique of INSU CNRS (DYFAMED), by UNEP/WMO (MEDPOL), and by a doctoral fellowship (sectoral grant B/87000259, E. R) of the Environmental Research Programme of the European Economic
Communities. We are grateful to T. C. Jickells, T. Church, and an anonymous reviewer for constructive comments.

\section{REFERENCES}

Arimoto, R., R. A. Duce, B. J. Ray, and C. K. Unni. Atmospheric trace elements at Enewetac Atoll, 2, Transport to the ocean by wet and dry deposition, J. Geophys. Res.. 90, 2391-2408, 1985.

Amold, M., A. Seghaier, D. Martin, P. Buat-Ménard, and R. Chesselet, Géchimie de I' aérosol marin au-dessus de la Méditerranée Occidentale, paper presented at the VI joumées d' études sur les pollutions marines en Méditerranée, Monaco, 1982.

Bergametti, G., Apports de matière par voie atmosphérique à la Mediterran Occidentale: Aspects géochimiques et météorologiques, Thesis, Univ. Paris 7, 1987.

Bergametti, G., A. L. Dutot, P. Buat-Ménard, R. Losno, and E. Remoudaki, Seasonal variability of the elemental composition of atmospheric aerosol particles over the norhwestem Mediterranean, Tellus, 41B, 353-361, 1989.

Boyle, E. A., S. D. Chapnick, G. T. Shen, and M. P. Bacon, Temporal variability of lead in the westem north Atlantic, J. Geophys. Res., 91 , 8573-8593, 1986.

Cambray, R. S., D. F. Jefferies, and G. Topping, An estimate of the input of atmospheric trace elements into the North Sea and the Clyde Sea (72-73), U.K. At. Energy Autho., Publ. AERE-R7733, 30pp, London, 1975.

Dulac, F., P. Buat-Ménard, M. Amold,and U. Ezat, Atmospheric input of trace metals to the westem Mediterranean Sea, 1, Factors controlling the variability of atmospheric concentrations, J. Geophys. Res., 92, 8437-8453, 1987.

Dulac, F., P. Buat-Ménard, U. Ezat, S. Melkj, and G. Bergametti, Atmospheric trace metals to the western Mediterranean Sea: Uncertainties in modelling dry deposition from cascade impactor data, Tellus, 41B, 362-378, 1989.

Feinberg, M., Reflexion prospective sur quelques concepts de la chimie analytique et sur sa demarche expérimentale, Thesis, Univ. Pierre et Marie Curie, Paris, 1984.

Flegal, A. R., and C. C. Patterson, Vertical concentration profiles of $\mathrm{Pb}$ in the central Pacific at $15 \mathrm{~N}$ and 20 S, Earth Planet. Sci. Lett., 64, 19$32,1983$.

Galloway, J. N., J. D. Thomton, S. A. Norton, H. L. Vol chok, and R. A. MacLean, Trace metals in atmospheric deposition: $A$ review and assessment, Atmos. Environ., 16, 1677-1700, 1982.

Hewith, C. N., and R. M. Harrison, Atmospheric concentrations and chemistry of alkyllead compounds and environmental alkylation of lead, Environ. Sci. Technol., 21, 260-266, 1987.

Imbard, M. Trajectoires: transport longue distance, Note CETI, Météorol. Natl., Paris, 1983.

Lambert, G., Eude du comportement des aerosols radioactifs artificiels, Applications à quelques problèmes de circulation atmosphérique, Thesis, Faculté des Sci. de l'Univ. de Paris, 1963.

Laumond, F., G. Copin-Monteguh, P. Courau, and E. Nicolas, Cadmium, copper and lead in the westem Mediterranean Sea, Mar. Chem., 15, 251-261, 1984.

Maring, H., D. Settle, P. Buat-Ménard, F. Dulac, and C. Patterson, Stable lead isotope tracers of air mass trajectories in the Mediterranean region, Nature, 330, 154-156, 1987. 
Pacyna, J., Estimation of the atmospheric emissions of trace elements from anthropogenic sources in Europe, Atmos. Environ., 18, 41-50, 1984.

Patterson, C. C., and D. M. Settle, Review of data on colian fluxes of industrial and natural lead to the lands and seas in remote regions on a global scale, Mar. Chem., 22, 137-162, 1987.

Schaule, B. K. and C. C. Patterson, Lead concentrations in the Northeast Pacific: Evidence for global anthropogenic perturbations, Earth Planet. Sci. Lett., 54, 97-116, 1981.

Schaule, B. K., and C. C. Patterson, Perturbations of the natural lead depth profile in the Sargasso Sea by industrial lead, in Trace Metals in Sea Water, Plenum, New York, 1982.

Settle, D. M., and C. C. Patterson, Magnitudes and sources of precipitation and dry deposition fluxes of industrial and natural leads to the North Pacific at Enewetak, J. Geophys. Res., 87, 8857-8869, 1982.
Sievering, H., Small particle dry deposition on natural waters: How large the uncertainty?, Almos. Environ., 18, 2271- 2272, 1984.

Slinn, S. A., and W. G. Slinn, Prediction for particle deposition on natural waters, Atmos.Environ., 14, 1013-1016,1980.

G. Bergametti and E. Remoudaki, Laboratoire de Physico-Chimie de l'Atmosphère, Université Paris 7, URA CNRS 1404, 2 Place Jussieu, F75251 Paris Cedex 05. France.

P. Buat-Ménard, Centre des Faibles Radioactivités, Laboratoire Mixte CNRS-CEA, F-91198 Gif-sur-Yvette Cedex, France.

\author{
Received February 23, 1989; \\ revised January 8, 1990; \\ accepted January 8, 1990.)
}

